\title{
Distinct Expression and Prognostic Values of GATA Transcription Factor Family in Human Ovarian Cancer.
}

Quan Zhou ( $\sim$ zhouquan8519@163.com )

Wuhan University Zhongnan Hospital

Yang Huai-jie

First People's Hospital of Yichang

Zuo Man-Zhen

First People's Hospital of Yichang

Ya-ling Tao

First People's Hospital of Yichang

\section{Research}

Keywords: GATA, ovarian cancer, prognosis, KM plotter

Posted Date: August 6th, 2020

DOI: https://doi.org/10.21203/rs.3.rs-52961/v1

License: (c) (i) This work is licensed under a Creative Commons Attribution 4.0 International License. Read Full License 


\section{Abstract}

Accumulated studies have provided controversial evidences of expression patterns and prognostic value of the GATA transcription factor family in human ovarian cancer. In the present study, we accessed the distinct expression and prognostic roles of 7 individual members of GATA family in ovarian cancer (OC) patients through Oncoming analysis, CCLE analysis, the Kaplan-Meier plotter (KM plotter) database, cBioPortal and Metascape. Our results indicated that GATA1, GATA3, GATA4 and TRPS1 mRNA expression was significantly higher in $O C$ than normal samples. High expression of GATA1, GATA2, and GATA4 were significantly correlated with better overall survival (OS), while increased GATA3 and GATA6 expression were associated with worse prognosis in OC patients. GATA1, GATA2, GATA3 and GATA6 were closely related to the different clinicopathological features of $O C$. The genetic variation and interaction of the GATA family may be closely related to the pathogenesis and prognosis of $\mathrm{OC}$, and the regulatory network composed of GATA family genes and their neighboring genes are mainly involved in Notch signaling pathway, Th1 and Th2 cell differentiation and Hippo signaling pathway. Our results might be beneficial for the better understanding of heterogeneity and complexity in the molecular biology of ovarian cancer, and paving a way for more accurate prediction of the prognosis of patients with OC.

\section{Introduction}

Ovarian cancer (OC) is the most cause of cancer-related death form of all gynecological malignancies [1, 2]. Although standard cytoreductive surgery and platinum based chemotherapy have improved overall survival and life quality, long-term survival of advanced OC patients remains poor[3]. Over $75 \%$ of patients are not early diagnosed until advanced stages, and the 5-year rate survival is less than $30 \%$, due to the lack of specific symptoms and efficiently prognostic biomarkers $[4,5]$. Therefore, further investigation on the mechanisms of OC tumorigenesis and tumor progression, and identification of potential effective and minimally prognostic markers and potential drug targets is still needed for OC patients[3].

The GATA protein family has been identified as one of the zinc finger DNA binding proteins that play an essential role during epithelial proliferation and development of diverse tissues[6]. Based on initial studies of their expression, GATA1, GATA2, and GATA3 were categorized as hematopoietic GATA factors, while GATA4, GATA5, and GATA6 were termed endodermal GATA factors [6, 7]. In biological function, GATA1 and GATA2 play pivotal roles in regulating cell cycle or proliferation[8]. GATA3 is not only an important transcriptional factor for T-cell development, but it is also involved in cellular proliferation, development, and differentiation in luminal epithelial and urothelial epithelium cells[9]. GATA4, GATA5 and GATA6 are expressed predominantly in endodermand mesoderm-derived tissues $[10,11]$. GATA4 and GATA5 tend to mark fully differentiated epithelial cells and confirmed as potential tumor suppressors[12], while GATA6 expresses in the immature proliferating cells in the intestinal crypts and classified as potential oncogene[13]. TRPS1 (trichorhinophalangeal syndrome-1) is a novel GATA transcription factor that has been found to be a critical activator of mesenchymal-to-epithelial transition (MET) during embryonic development in a number of tissues[14]. There is growing evidence that deregulation of GATA expression is a common occurrence in several human malignancies, and distinctive role of individual GATA member 
in tumor tumorigenesis and progression [6, 7, 15]. Such as breast[16], colon[17], lung[18], gastric[19] and pancreatic cancer[20], as well as $\mathrm{OC}[21-26]$. These proteins are considered having potential value to be adopted as novel biomarkers in the detection and accurate prediction of many kinds of tumors.

Although GATA has been identified as a crucial transcription factors in a variety of hematogenous malignancies and solid tumors, and several GATA family members (GATA3, GATA4 and GATA6) have been shown to be related to prognosis in OC patients[21-26]. The roles of distinct different GATA members in contribution to tumorigenesis and development of $\mathrm{OC}$ are still lacking. In the current study, we extended the research field to $\mathrm{OC}$ based on large databases, with purpose of determining the expression pattern of distinct GATA family members in OC.

\section{Material And Methods Oncomine analysis}

The individual gene mRNA expression levels of GATA family members (GATA1, GATA2, GATA3, GATA4, GATA5, GATA6 and TRPS1) were determined through analysis in ONCOMINE database (www.oncomine.org), which is a publicly accessible online database with cancer microarray information to facilitate discovery from genome-wide expression analyses[27, 28]. In this study, students'-test was used to generate a $p$-value for comparison between cancer specimens and normal control datasets. The fold change was defined as 1.0, $p$ value was set up at 0.05 and top $10 \%$ gene rank as threshold.

\section{CCLE analysis}

The mRNA levels of GATA members in a series of cancers were analyzed by CCLE database (https:// portals.broadinstitute.org/ccle/home), which is an online encyclopedia of a compilation of gene expression, chromosomal copy number and massively parallel sequencing data from 947 human cancer cell lines, to facilitate the identification of genetic, lineage, and predictors of drug sensitivity[29].

\section{The Kaplan-Meier plotter and OncoLnc database analysis}

The prognostic significance of the messenger RNA (mRNA) expression of GATA family genes in OC was evaluated using the Kaplan-Meier plotter (www.kmplot.com), an online database including gene expression data and clinical data[30]. In this database, all OC patients' gene expressions and survival information were established from the Gene Expression Omnibus (GEO), The Cancer Genome Atlas cancer datasets (TCGA), and the Cancer Biomedical informatics Grid (caBIG)[31]. With the purpose to assess prognostic value of a specific gene, patients were split into high and low expression groups by the median values of mRNA expression. Clinical data of OC patients, including pathological grade, clinical stage, TP53 mutation status, and treatment, were collected. Then, 7 individual members of the GATA family were entered into the database (http://kmplot.com/analysis/index.php? $\mathrm{p}=$ service\&cancer=ovar) to create Kaplan-Meier survival plots using the online KM plotter[32]. HRs, 95\% Cls, and log rank value were determined and displayed on the webpage. A $p$ value $<0.05$ was considered to be statistically significant 
to reduce the false positive rate. Simultaneously, OncoLnc (www.oncolnc.org/) online tools to validate the correlation between the expression of each GATA family genes and the prognosis of patients with OC, which combines prognostic data from The Cancer Genome Atlas (TCGA) database with mRNA, miRNA or IncRNA expression levels. The expression and prognosis data for each gene were downloaded, and Kaplan-Meier curves were drawn using online tools.

\section{cBioPortal analysis}

The cBioPortal for Cancer genomics is an open access resource (http://www.cbioportal.org/), providing integrative analysis of complex cancer genomics and clinical profiles from 105 cancer studies in TCGA pipeline[33]. The frequency of GATA family gene alterations (amplification, deep deletion, missense mutations), copy-number variance (CNV) from GISTIC and mRNA expression z-scores (RNA Seq V2 RSEM) were assessed using the cBioPortal for Cancer Genomics database and TCGA. In addition, coexpression and network was calculated according to the cBioPortal's online instruction[32].

\section{Functional enrichment analysis}

Metascape (http://metascape.org) is a free well-maintained, user-friendly gene-list analysis tool for gene annotation and analysis resource. In this study, Metascape was used to conduct pathway and process enrichment analysis of GATA family members and neighboring genes. The Gene Ontology (GO) terms for the biological process (BP), cellular component (CC) and molecular function (MF) categories as well as Kyoto Encyclopedia of Genes and Genomes (KEGG) pathways were enriched based on Metascape online tool. Only terms with $P$ value $<0.01$, minimum count 3 , and enrichment factor $>1.5$ were concerned as significant. Molecular Complex Detection (MCODE) algorithm was further applied to identify densely connected network components.

\section{Results}

\section{The mRNA expression levels of GATA family members in OC.}

To address the mRNA expression differences of GATA family between tumor and normal tissues in ovarian cancer, we performed an analysis using the Oncomine database. As shown in Fig. 1, ONCOMINE analysis revealed that GATA1, GATA2, GATA3, GATA4 and TRPS1 mRNA expression was significantly higher in OC than normal samples. GATA1 transcripts were 1.082 fold elevated in OC samples as compared with normal tissues in a dataset with 594 samples that derived from TCGA (the Cancer Genome Atlas) database. GATA2 was 1.211-fold elevated in OC samples as compared with normal tissues $(p=9.89 \mathrm{E}-6)$. GATA3 was 1.138 -fold elevated in OC samples as compared with normal tissues ( $p$ $=1.48 \mathrm{E}-7)$. GATA4 was 1.201-fold elevated in OC samples as compared with normal tissues $(p=6.23 \mathrm{E}-5)$. In addition, TRPS1 was 1.269-fold elevated in OC samples as compared with normal tissues $(p=4.00 \mathrm{E}-5)$. We chose the probe with the highest expression fold change as the Fig. 1 display when multiple probes correspond to the same GATA family member. However, no significant difference was found in the mRNA 
level of other GATA members, including GATA5 (-2.311 fold change, $p=0.996)$ and GATA6 $(-2.529$ fold change, $p=1.000$ ) between OC samples and normal controls. CCLE analysis demonstrated that although the mRNA expression levels of GATA1 and GATA2 ranked the 14th and 16th highest in OC among different cancer cell types, the expression levels of GATA1 and GATA2 in ovarian cancer cells are generally low, (shown in green frame).(Fig. 2).

\section{Prognostic values of GATA family members in OC patients.}

We respectively examined the prognostic ability of the mRNA expression of individual GATA family members in OC patients in www.Kmplot.com. Five members were significantly associated with prognosis in $\mathrm{OC}$ patients (Fig. 3). We chose the probe with the largest sample size as the target probe for further analysis when multiple probes correspond to the same GATA family member. We observed that high expression of GATA1, GATA2, and GATA4 were significantly correlated with better overall survival (OS), while increased GATA3 and GATA6 expression were associated with worse prognosis in OC patients. The mRNA levels of GATA5 and TRPS1 were not correlated with OS, although the expression of GATA5 (hazard ratio $[H R]=0.8295 \%$ confidence interval $[C l: 0.67-1.00, p=0.0551$ ) was modestly associated with poor survival. The prognostic values of GATA family members were assessed in different pathological histology subtypes of OC, including serous and endometrioid. As shown in Table 1, high mRNA expression of GATA4 was correlated with longer OS, whereas increased GATA6 and TRPS1 mRNA expression were correlated with better OS in serous OC patients. In endometrioid OC, increased GATA6 expression was associated with better prognosis. The remaining GATA family members were not significantly associated with prognosis in serous or endometrioid OC. Simultaneously, OncoLnc analysis demonstrated that abnormal expression of GATA2 and GATA4 was correlated with OS in OC patients (Logrank $P=0.045$ and 0.042 ). However, the expression of other GATA family members was not statistically associated with the prognosis of patients with OC (Supplemental Information. 1). 
Table 1

Correlation of GATA gene expression level with overall survival in ovarian cancer patients with different pathological histology:

\begin{tabular}{|c|c|c|c|c|c|c|}
\hline GATA family & Affymetrix ID & Pathological grades & Cases & HR & $95 \% \mathrm{Cl}$ & $p$-value \\
\hline \multirow[t]{2}{*}{ GATA-1 } & 210446_at & Serous & 1207 & 1.11 & $0.96-1.30$ & 0.17 \\
\hline & & Endometrioid & 47 & 0.48 & $0.08-2.85$ & 0.41 \\
\hline \multirow[t]{2}{*}{ GATA-2 } & 207954_at & Serous & 1207 & 0.86 & $0.73-1.02$ & 0.075 \\
\hline & & Endometrioid & 47 & 3.51 & $0.59-21.09$ & 0.14 \\
\hline \multirow[t]{2}{*}{ GATA-3 } & 209603_at & Serous & 1207 & 1.16 & $1.00-1.36$ & 0.051 \\
\hline & & Endometrioid & 37 & - & - & - \\
\hline \multirow[t]{2}{*}{ GATA-4 } & 205517_at & Serous & 1207 & 0.76 & $0.64-0.91$ & 0.0021 \\
\hline & & Endometrioid & 37 & 6.25 & $0.70-56.03$ & 0.061 \\
\hline \multirow[t]{2}{*}{ GATA-5 } & 238095_at & Serous & 523 & 0.84 & $0.67-1.05$ & 0.13 \\
\hline & & Endometrioid & 30 & 0.14 & $0.01-1.38$ & 0.05 \\
\hline \multirow[t]{2}{*}{ GATA-6 } & 210002_at & Serous & 1207 & 1.43 & $1.21-1.68$ & $1.5 e-5$ \\
\hline & & Endometrioid & 37 & 5.53 & $0.92-33.17$ & 0.035 \\
\hline \multirow[t]{2}{*}{ TRPS1 } & 218502_s_at & Serous & 1104 & 1.44 & $1.25-1.67$ & $5.3 e-7$ \\
\hline & & Endometrioid & 51 & 0.28 & $0.06-1.22$ & 0.071 \\
\hline \multicolumn{7}{|c|}{ Notes: The bold values indicate that the results are statistically significant. } \\
\hline \multicolumn{7}{|l|}{ Abbreviations: } \\
\hline HR, hazard $\mathrm{r}$ & Cl, confide & terval. & & & & \\
\hline
\end{tabular}

We made further efforts to assess the relationship between individual GATA family members and other clinicopathological features, such as pathological grade (Table 2), clinical stage (Table 3), and TP53 status (Table 4) in OC patients. As shown in Table 2, high mRNA expression of GATA3 was associated with worse OS in pathological grade $\varangle+\square \mathrm{OC}$ patients. In pathological grade $\varangle+\square \mathrm{OC}$ patients, elevated mRNA expression of GATA1, GATA2 and GATA4 were associated with better OS, but high GATA5 and TRPS1 mRNA expression linked to poor OS. As shown in Table 3, only increased expression of GATA3 and GATA5 were associated with worse OS in clinical stage I patients. For clinical stage II OC patients, only high expression of GATA4 was associated with better OS. In clinical stage III OC patients, high expression of GATA2, GATA4 and GATA5 correlated with better OS; in contrast, elevated GATA6 expression were associated with worse OS. For clinical stage IV patients, high level of GATA6 was associated with worse OS. Table 4 shows that the correlation between GATA family member expression and TP53 status. High expression of GATA1, GATA2, GATA3, GATA6 and TRPS1 were associated with poor OS in OC 
patients harbouring mutated TP53. In contrast, increased GATA2 and GATA3 mRNA expression were linked to better prognosis, and high expression of GATA6 was associated with linked worse OS in OC patients with wild-type TP53.

Table 2

Correlation of GATA gene expression level with overall survival in ovarian cancer patients with different pathological grade

\begin{tabular}{|c|c|c|c|c|c|c|}
\hline GATA family & Affymetrix ID & clinical stage & Cases & HR & $95 \% \mathrm{Cl}$ & $p$-value \\
\hline \multirow[t]{2}{*}{ GATA1 } & 210446_at & $\nabla+\square$ & 135 & 0.68 & $0.30-1.54$ & 0.36 \\
\hline & & $\nabla+\rrbracket$ & 1220 & 0.76 & $0.64-0.90$ & 0.0018 \\
\hline \multirow[t]{2}{*}{ GATA2 } & 207954_at & $\nabla+\rrbracket$ & 135 & 0.52 & $0.22-1.20$ & 0.12 \\
\hline & & $\nabla+\rrbracket$ & 1220 & 0.81 & $0.69-0.96$ & 0.012 \\
\hline \multirow[t]{2}{*}{ GATA3 } & 209603_at & $\nabla+\square$ & 135 & 2.54 & $1.15-5.61$ & 0.017 \\
\hline & & $\nabla+\square$ & 1220 & 0.85 & $0.72-1.01$ & 0.072 \\
\hline \multirow[t]{2}{*}{ GATA4 } & 205517_at & $\nabla+\rrbracket$ & 135 & 0.65 & $0.29-1.46$ & 0.29 \\
\hline & & $\nabla+\rrbracket$ & 1220 & 0.82 & $0.70-0.97$ & 0.018 \\
\hline \multirow[t]{2}{*}{ GATA5 } & 238095_at & $\nabla+\rrbracket$ & 83 & 1.87 & $0.66-5.26$ & 0.23 \\
\hline & & $\nabla+\rrbracket$ & 487 & 0.80 & $0.64-1.01$ & 0.056 \\
\hline \multirow[t]{2}{*}{ GATA6 } & 217728_at & $\nabla+\rrbracket$ & 135 & 2.12 & $0.96-4.68$ & 0.057 \\
\hline & & $\nabla+\rrbracket$ & 1220 & 1.58 & $1.34-1.85$ & $3.2 \mathrm{e}-8$ \\
\hline \multirow[t]{2}{*}{ TRPS1 } & 218502_s_at & $\nabla+\rrbracket$ & 135 & 1.87 & $0.81-4.32$ & 0.14 \\
\hline & & $\nabla+\rrbracket$ & 1220 & 1.18 & $1.01-1.37$ & 0.035 \\
\hline \multicolumn{7}{|c|}{ Notes: The bold values indicate that the results are statistically significant. } \\
\hline Abbrevi & , hazar & 10 & val. & & & \\
\hline
\end{tabular}


Table 3

Correlation of GATA gene expression level with overall survival in ovarian cancer patients with different clinical stage

\begin{tabular}{|c|c|c|c|c|c|c|}
\hline GATA family & Affymetrix ID & clinical stage & Cases & HR & $95 \% \mathrm{Cl}$ & $p$-value \\
\hline \multirow[t]{4}{*}{ GATA-1 } & 210446_at & 口 & 56 & 0.66 & $0.26-1.69$ & 0.38 \\
\hline & & प & 324 & 0.81 & $0.58-1.13$ & 0.20 \\
\hline & & प & 1015 & 0.89 & $0.74-1.07$ & 0.21 \\
\hline & & प & 20 & 0.37 & $0.10-1.35$ & 0.12 \\
\hline \multirow[t]{4}{*}{ GATA-2 } & 207954_at & प & 56 & 0.60 & $0.19-1.87$ & 0.38 \\
\hline & & 口 & 324 & 0.83 & $0.61-1.13$ & 0.24 \\
\hline & & प & 1015 & 0.78 & $0.65-0.94$ & 0.0083 \\
\hline & & 口 & 20 & 0.64 & $0.22-1.88$ & 0.41 \\
\hline \multirow[t]{4}{*}{ GATA-3 } & 209603_at & 口 & 56 & 7.64 & $1.01-57.67$ & 0.02 \\
\hline & & 口 & 324 & 1.36 & $0.98-1.89$ & 0.066 \\
\hline & & 口 & 1015 & 1.15 & $0.98-1.36$ & 0.095 \\
\hline & & $\square$ & 20 & 1.65 & $0.64-4.27$ & 0.29 \\
\hline \multirow[t]{4}{*}{ GATA-4 } & 205517_at & $\square$ & 74 & 4.28 & $0.55-33.2$ & 0.13 \\
\hline & & प & 61 & 0.34 & $0.11-1.03$ & 0.045 \\
\hline & & 口 & 1044 & 0.81 & $0.68-0.96$ & 0.017 \\
\hline & & 口 & 176 & 1.30 & $0.82-2.05$ & 0.26 \\
\hline \multirow[t]{4}{*}{ GATA-5 } & 238095_at & 口 & 41 & 4.12 & $1.30-12.99$ & 0.0088 \\
\hline & & 口 & 162 & 0.77 & $0.47-1.24$ & 0.27 \\
\hline & & 口 & 392 & 0.75 & $0.58-0.96$ & 0.022 \\
\hline & & 口 & 18 & - & - & - \\
\hline \multirow[t]{4}{*}{ GATA-6 } & 210002_at & 口 & 56 & 1.65 & $0.63-4.31$ & 0.30 \\
\hline & & 口 & 324 & 1.24 & $0.89-1.72$ & 0.20 \\
\hline & & 口 & 1015 & 1.41 & $1.19-1.67$ & $6 e-05$ \\
\hline & & प & 20 & 6.38 & $1.75-23.20$ & 0.0017 \\
\hline
\end{tabular}

Notes: The bold values indicate that the results are statistically significant.

Abbreviations: HR, hazard ratio; $\mathrm{Cl}$, confidence interval. 


\begin{tabular}{|lcccccc|}
\hline GATA family & Affymetrix ID & clinical stage & Cases & HR & 95\% Cl & p-value \\
\hline TRPS1 & 218502_s_at & $\square$ & 56 & 1.80 & $0.70-4.66$ & 0.22 \\
& & 324 & 1.33 & $0.98-1.80$ & 0.068 \\
& & 1015 & 1.12 & $0.94-1.34$ & 0.21 \\
& & 20 & 2.79 & $0.77-10.05$ & 0.10 \\
\hline
\end{tabular}

Table 4

Correlation of GATA gene expression level with overall survival in ovarian cancer patients with different TP53 mutation status

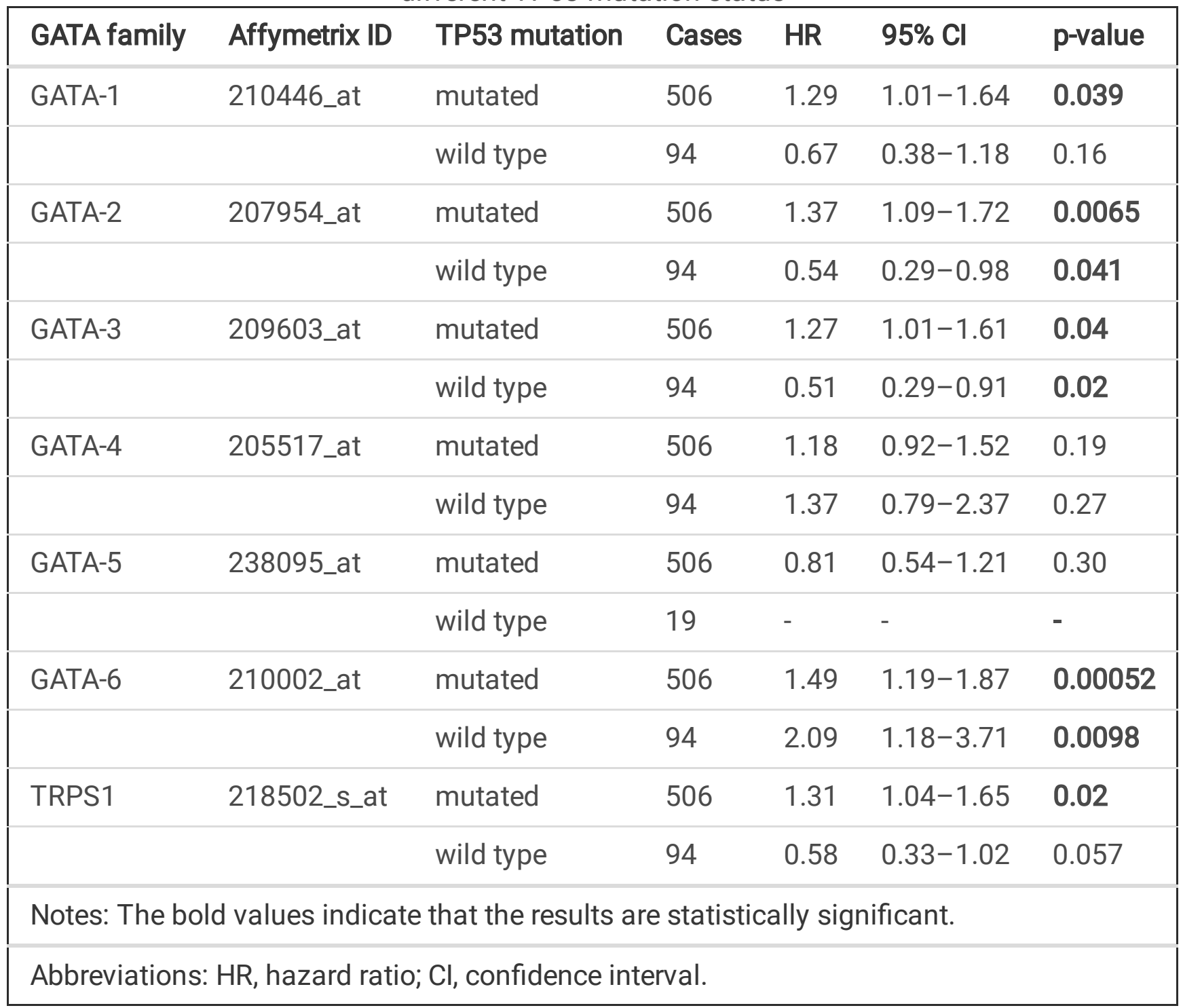

\section{Genetic alteration and neighbor gene network of GATA family members in patients with OC}


Alteration frequency of GATAs mutation in OC was analyzed by using cBioPortal. A total of 1,766 patients from four dataset of ovarian serous cystadenocarcinoma (TCGA Provisional), ovarian serous cystadenocarcinoma (TCGA, Nature 2011), ovarian serous cystadenocarcinoma (TCGA, PanCancer Atlas), ovarian serous cystadenocarcinoma (TCGA, Provisional) and Small Cell Carcinoma of the Ovary (MSKCC, Nat Genet 2014) were analyzed. Among this datasets analyzed, gene set/pathway is altered in $704(40 \%)$ of queried samples for the gene sets submitted for analysis (Fig. 4a). The percentages of genetic alterations in GATA family members for OC varied from $4-23 \%$ for individual genes based on TCGA Provisional dataset (GATA1, 4\%; GATA2,4\%; GATA3,5\%; GATA4,6\%; GATA5,10\%; GATA6,2.8\% and TRPS1,23\%) (Fig. 4b). Pearson correlation analysis was conducted using expression data (RNA Seq V2 RSEM) of GATA family members collected from the cBioPortal online tool for OC. The results indicated that there is a significant positive correlation among GATA2 with GATA4 and GATA5. However, GATA1 with GATA2 and GATA6 had a significant negative correlation (Fig. 4c). We then constructed the network for GATA and the 50 most frequently altered neighbor genes using the cBioPortal. The results showed that $A K T 1, A R N T, C A 13, C A 14, C A 2, C A 3, C A 4, C A 5 B, C A 6, C A 7, C A 8, C H D 4, C R E B B P$, EDN1, EP300, GATA1, GATAD2A, GATAD2B, GIP, HDAC1, HDAC2, HDAC3, HDAC4, HES1, HEY1, HEY2, HIPK1, HIPK2, IL 10, ISL 1, JUN, MAML 1, MAML2, MAPK1, MAPK3, MBD3, MTA2, MYB, NFATC2, NOTCH1, PAX6, PRKACA, RBBP4, RBBP7, RBPJ, SMAD3, SMAD4, TP73, WWTR1, ZFPM1 and ZFPM2 were closely associated with GATA alterations and functions(Fig. 4d). The results of Kaplan-Meier plotter and log-rank test indicated no significant difference in OS and disease-free survival (DFS) or progression-free survival (PFS) between the cases with alterations in one of the query genes and those without alterations in any query genes ( $P$ values, 0.0651 and 0.0736 respectively; Fig. 4 e and $5 f$ ).

\section{Functions enrichment analysis of GATA family members in patients with OC}

The functions of GATA family members and their neighboring genes were predicted by analyzing gene ontology (GO) and Kyoto Encyclopedia of Genes and Genomes (KEGG) in Metascape. As shown in Fig. 5a-d and Table 5, the GO enrichment items were classified into three functional groups: biological process group, molecular function group, and cellular component group. The GATA family members and their neighboring genes were mainly enrichment in the heart development, embryonic organ development, regulation of binding, response to wounding, endocrine system development, regulation of Notch signaling pathway, muscle cell differentiation, regulation of hemopoiesis, regulation of stem cell differentiation, cardiac muscle hypertrophy, cytokine production, animal organ formation, muscle cell development, cellular response to hormone stimulus and response to heat; The molecular functions that these genes were mainly expressed in transcription regulatory region sequence-specific DNA binding, transcription factor binding and carbonate dehydratase activity; The cellular components that these genes were involve in the transcriptional repressor complex and transcription factor complex. The top 9 KEGG pathways for GATA family members and their neighboring genes are shown in Fig. $5 \mathrm{~d}$ and Table 5. Among these pathways, the Notch signaling pathway, Th1 and Th2 cell differentiation and Hippo 
signaling pathway were found to relate to multiple tumor development, and it be involved in OC tumorigenesis and pathogenesis. 
Table 5

Functions enrichment analysis of GATA family members in ovarian cancer patients.

\begin{tabular}{|c|c|c|c|c|c|c|}
\hline GO & Category & Description & Count & $\%$ & $\log 10(P)$ & $\log 10(q)$ \\
\hline G0:0000976 & $\begin{array}{l}\text { GO } \\
\text { Molecular } \\
\text { Functions }\end{array}$ & $\begin{array}{l}\text { transcription regulatory } \\
\text { region sequence-specific } \\
\text { DNA binding }\end{array}$ & 31 & 54.39 & -30.16 & -25.82 \\
\hline GO:0008134 & $\begin{array}{l}\text { GO } \\
\text { Molecular } \\
\text { Functions }\end{array}$ & $\begin{array}{l}\text { transcription factor } \\
\text { binding }\end{array}$ & 29 & 50.88 & -29.79 & -25.75 \\
\hline G0:0017053 & $\begin{array}{l}\text { GO Cellular } \\
\text { Components }\end{array}$ & $\begin{array}{l}\text { transcriptional repressor } \\
\text { complex }\end{array}$ & 16 & 28.07 & -25.93 & -22.49 \\
\hline GO:0007507 & $\begin{array}{l}\text { GO } \\
\text { Biological } \\
\text { Processes }\end{array}$ & heart development & 24 & 42.11 & -23.46 & -20.07 \\
\hline G0:0048568 & $\begin{array}{l}\text { GO } \\
\text { Biological } \\
\text { Processes }\end{array}$ & $\begin{array}{l}\text { embryonic organ } \\
\text { development }\end{array}$ & 22 & 38.60 & -23.18 & -19.84 \\
\hline GO:0004089 & $\begin{array}{l}\text { GO } \\
\text { Molecular } \\
\text { Functions }\end{array}$ & $\begin{array}{l}\text { carbonate dehydratase } \\
\text { activity }\end{array}$ & 9 & 15.79 & -19.73 & -16.59 \\
\hline hsa00910 & $\begin{array}{l}\text { KEGG } \\
\text { Pathway }\end{array}$ & Nitrogen metabolism & 9 & 15.79 & -19.40 & -16.71 \\
\hline GO:0051098 & $\begin{array}{l}\text { GO } \\
\text { Biological } \\
\text { Processes }\end{array}$ & regulation of binding & 18 & 31.58 & -18.58 & -15.58 \\
\hline GO:0009611 & $\begin{array}{l}\text { GO } \\
\text { Biological } \\
\text { Processes }\end{array}$ & response to wounding & 21 & 36.84 & -17.75 & -14.83 \\
\hline G0:0035270 & $\begin{array}{l}\text { GO } \\
\text { Biological } \\
\text { Processes }\end{array}$ & $\begin{array}{l}\text { endocrine system } \\
\text { development }\end{array}$ & 12 & 21.05 & -15.67 & -12.95 \\
\hline G0:0008593 & $\begin{array}{l}\text { GO } \\
\text { Biological } \\
\text { Processes }\end{array}$ & $\begin{array}{l}\text { regulation of Notch } \\
\text { signaling pathway }\end{array}$ & 11 & 19.30 & -15.18 & -12.50 \\
\hline hsa04330 & $\begin{array}{l}\text { KEGG } \\
\text { Pathway }\end{array}$ & $\begin{array}{l}\text { Notch signaling } \\
\text { pathway }\end{array}$ & 9 & 15.79 & -14.59 & -12.20 \\
\hline GO:0042692 & $\begin{array}{l}\text { GO } \\
\text { Biological } \\
\text { Processes }\end{array}$ & $\begin{array}{l}\text { muscle cell } \\
\text { differentiation }\end{array}$ & 15 & 26.32 & -13.90 & -11.34 \\
\hline
\end{tabular}

Notes: The bold values indicate that the results are statistically significant.

Abbreviations: GO, Gene Ontology; KEGG, Kyoto Encyclopedia of Genes and Genomes. 


\begin{tabular}{|c|c|c|c|c|c|c|}
\hline GO & Category & Description & Count & $\%$ & $\log 10(P)$ & $\log 10(q)$ \\
\hline GO:1903706 & $\begin{array}{l}\text { GO } \\
\text { Biological } \\
\text { Processes }\end{array}$ & $\begin{array}{l}\text { regulation of } \\
\text { hemopoiesis }\end{array}$ & 15 & 26.32 & -13.32 & -10.81 \\
\hline GO:2000736 & $\begin{array}{l}\text { GO } \\
\text { Biological } \\
\text { Processes }\end{array}$ & $\begin{array}{l}\text { regulation of stem cell } \\
\text { differentiation }\end{array}$ & 9 & 15.79 & -13.14 & -10.68 \\
\hline GO:0003300 & $\begin{array}{l}\text { GO } \\
\text { Biological } \\
\text { Processes }\end{array}$ & $\begin{array}{l}\text { cardiac muscle } \\
\text { hypertrophy }\end{array}$ & 10 & 17.54 & -13.13 & -10.67 \\
\hline GO:0001816 & $\begin{array}{l}\text { GO } \\
\text { Biological } \\
\text { Processes }\end{array}$ & cytokine production & 17 & 29.82 & -12.30 & -9.95 \\
\hline hsa04658 & $\begin{array}{l}\text { KEGG } \\
\text { Pathway }\end{array}$ & $\begin{array}{l}\text { Th1 and Th2 cell } \\
\text { differentiation }\end{array}$ & 9 & 15.79 & -11.91 & -9.92 \\
\hline GO:0005667 & $\begin{array}{l}\text { GO Cellular } \\
\text { Components }\end{array}$ & $\begin{array}{l}\text { transcription factor } \\
\text { complex }\end{array}$ & 13 & 22.81 & -11.56 & -9.28 \\
\hline hsa05169 & $\begin{array}{l}\text { KEGG } \\
\text { Pathway }\end{array}$ & $\begin{array}{l}\text { Epstein-Barr virus } \\
\text { infection }\end{array}$ & 10 & 17.54 & -10.21 & -8.29 \\
\hline hsa05161 & $\begin{array}{l}\text { KEGG } \\
\text { Pathway }\end{array}$ & Hepatitis B & 9 & 15.79 & -10.14 & -8.29 \\
\hline G0:0048645 & $\begin{array}{l}\text { GO } \\
\text { Biological } \\
\text { Processes }\end{array}$ & animal organ formation & 7 & 12.28 & -9.74 & -7.59 \\
\hline GO:0055001 & $\begin{array}{l}\text { GO } \\
\text { Biological } \\
\text { Processes }\end{array}$ & muscle cell development & 9 & 15.79 & -9.43 & -7.31 \\
\hline G0:0032870 & $\begin{array}{l}\text { GO } \\
\text { Biological } \\
\text { Processes }\end{array}$ & $\begin{array}{l}\text { cellular response to } \\
\text { hormone stimulus }\end{array}$ & 14 & 24.56 & -9.04 & -6.98 \\
\hline GO:0009408 & $\begin{array}{l}\text { GO } \\
\text { Biological } \\
\text { Processes }\end{array}$ & response to heat & 8 & 14.04 & -8.72 & -6.68 \\
\hline hsa05321 & $\begin{array}{l}\text { KEGG } \\
\text { Pathway }\end{array}$ & $\begin{array}{l}\text { Inflammatory bowel } \\
\text { disease (IBD) }\end{array}$ & 4 & 7.02 & -4.71 & -3.66 \\
\hline hsa04390 & $\begin{array}{l}\text { KEGG } \\
\text { Pathway }\end{array}$ & $\begin{array}{l}\text { Hippo signaling } \\
\text { pathway }\end{array}$ & 4 & 7.02 & -3.25 & -2.40 \\
\hline hsa05031 & $\begin{array}{l}\text { KEGG } \\
\text { Pathway }\end{array}$ & Amphetamine addiction & 3 & 5.26 & -3.20 & -2.37 \\
\hline \multicolumn{7}{|c|}{ Notes: The bold values indicate that the results are statistically significant. } \\
\hline
\end{tabular}




\begin{tabular}{|lllllll|}
\hline G0 & Category & Description & Count & $\%$ & Log10(P) & Log10(q) \\
\hline hsa05418 & $\begin{array}{l}\text { KEGG } \\
\text { Pathway }\end{array}$ & $\begin{array}{l}\text { Fluid shear stress and } \\
\text { atherosclerosis }\end{array}$ & 3 & 5.26 & -2.29 & -1.57 \\
\hline \multicolumn{2}{l}{ Notes: The bold values indicate that the results are statistically significant. } \\
\hline
\end{tabular}

In addition, to better understand the relationship between GATA family members and OC, we performed a Metascape protein-protein interaction (PPI) enrichment analysis and module analysis of the PPI network. The PPI network and MCODE components identified in the gene lists and shown in Fig. 6a-d. The PPI network were significantly associated with heart development, embryonic organ development and chordate embryonic development, while in three significant modules, GO term enrichment analysis of biological processes showed that the genes in these modules were mainly associated with ATPdependent chromatin remodeling, histone deacetylation, protein deacetylation, chordate embryonic development, embryo development ending in birth or egg hatching and in utero embryonic development.

\section{Discussion}

GATA family has been widely recognized as pivotal transcription factors in the development and differentiation of various cell types in vertebrates. Increasing evidence has shown that altered expression of GATA factors plays an important role in dedifferentiation of ovarian carcinogenesis. However, the exact role of GATA expression in $\mathrm{OC}$ is still controversial. In the current study, we comprehensively examined the expression patterns and prognosis analyses of individual GATA family members in OC using the Oncomine database, the CCLE database, the KM plotter, cBioPortal and Metascape. Our analysis suggested that, among the members of the GATA family, GATA1, GATA3, GATA4 and TRPS1 mRNA expression was significantly higher in $\mathrm{OC}$ than normal samples. The mRNA expression level of GATA1 and GATA2 in OC listed the moderate highest among all cancer types using the CCLE analysis. More importantly, survival analysis indicated that high expression of GATA1, GATA2, and GATA4 were significantly correlated with better OS, while increased GATA3 and GATA6 expression were associated with worse prognosis in OC patients. We further assessed the prognostic value of GATA in different pathological grades, clinical stages and TP53 mutation status of OC patients. The results showed that GATA1, GATA2, GATA3 and GATA6 were closely related to the different clinicopathological features and treatment of OC. Then, we tried to systematically explore the genetic alteration, correlation and potential functions of GATA family numbers in OC. Our findings confirmed that the genetic variation and interaction of the GATA family may be closely related to the pathogenesis and prognosis of $O C$, and the regulatory network composed of GATA family genes and their neighboring genes are mainly involved in Notch signalling pathway, Th1 and Th2 cell differentiation and Hippo signalling pathway.

GATA1, the first recognised member of the GATA family, is essential for erythropoiesis, megakaryocyte maturation, and eosinophil production[34]. The observations in human patients confirmed the critical role for GATA1 in erythroid and megakaryocytes development, and GATA1 mutations may be closely related to 
two neoplastic diseases: transient myeloproliferative disorder and acute megakaryoblastic leukemia[35]. However, its role in solid tumour has not yet been fully elucidated[36]. Our results demonstrated that increased expression of GATA1 was correlated with significantly better OS for all OC patients, but not in serous or endometrioid subtype patients. This may be due to the small sample size of these two subtypes. Two previous studies found that GATA1 and its phosphorylation may play an important role in the metastasis of breast cancer, and GATA1 can be used as an independent prognostic marker for breast cancer $[37,38]$. Unfortunately, as far as I know, no molecular biology studies have directly explored the prognostic value of GATA1 for OC. This study further shows that high expression of GATA1 indicated a better OS for OC patients with high stage $(\nabla+\rrbracket)$. Furthermore, the $11 \%$ of genetic alterations in GATA1 for OC based on TCGA Provisional dataset, and GATA1 with GATA2 and GATA6 had a significant negative correlation through Pearson correlation analysis. Due to the lack of relevant research, the conclusion of our study on GATA1 needs to be further confirmed.

GATA2 is identified as a critical regulator of growth, differentiation and survival of hematopoietic stem cells $[39,40]$. Increasing evidence has shown that GATA2 expression is correlated with hematologic pathophysiologies and the proliferation and progression of solid tumors[40]. Upregulated GATA2 expression has been implicated in several tumour types, such as breast cancer [41], colorectal cancer [42] and liver cancer [43]. Moreover, recent studies confirmed that GATA2 overexpression in prostate cancer increases cellular motility and invasiveness, proliferation, tumorigenicity, and resistance to standard therapies[40]. In our study, high expression of GATA2 was significantly associated with better OS, especially in pathological grade $₫+\square$ OC patients. In addition, increased GATA2 expression was linked to better prognosis in OC patients with wild-type TP53 in our analysis.

GATA3 is a "master regulator" in both mouse and human development that plays a critical role in multiorgan development and regulates tissue specific cellular differentiation[44]. It is reported to be abnormal expressed in breast and urothelial carcinomas and, hence, has been used as a marker and extensively investigated in these cancers $[44,45]$. Recent evidence suggests that GATA3 as a strong and independent predictor of clinical outcome in human luminal breast cancer $[16,46]$. Lower GATA3 expression is strongly associated with higher histologic grade, poor differentiation, positive lymph nodes, ER - and progesterone receptor $(P R)$ negative status, HER2/neu overexpression and all other indicators of poor prognosis[46]. The presumed role of GATA3 in the pathogenesis of OC, however, still remains unclear [47]. Our analysis showed that overexpression of GATA3 was associated with worse prognosis in OC patients, especially in early clinical stages, patients undergoing optimal surgery and two pathological types of OC.

GATA4, GATA5, and GATA6 are expressed predominantly in endoderm and mesoderm-derived tissues [10]. As to the intestinal cell types of expression, it has been suggested that GATA4 and GATA5 tend to mark fully differentiated epithelial cells [48], while GATA6 is expressed in the immature proliferating cells in the intestinal crypts [49]. Thus, GATA4 and GATA5 is currently considered potential tumour suppressors, however, GATA6 can be used as a potential oncogene[6]. Altered expression of GATA4, GATA5, and GATA6 are associated with abroad range of tumours emerging from the gastrointestinal tract [50], lungs [51] and brain [52]. Moreover, some studies reported that methylation in the GATA4 and GATA6 promoter region

Page $15 / 26$ 
could play an important role in ovarian carcinogenesis, elevated GATA4 and lower GATA6 mRNA levels are associated with better prognosis in ovarian tumours[21, 22, 25]. We found a similar result, with high GATA4 expression being related to better prognosis in OC patients, and increased GATA6 expression were associated with worse prognosis in $\mathrm{OC}$ patients. Although several studies have shown that the expression and methylation states of GATA5 may be involved in ovarian carcinogenesis. The biologic role and the prognostic effect of GATA5 in OC patients are still poorly understood. Our study suggests that there is a significant positive correlation among GATA2 with GATA4 and GATA5, the $10 \%$ of genetic alterations in GATA5 for OC based on TCGA dataset. Regrettably, the expression level of GATA5 is not related to the OS of OC.

\section{Conclusion}

In conclusion, the members of the GATA family, GATA1, GATA3, GATA4 and TRPS1 mRNA expression was significantly higher in $\mathrm{OC}$ than normal samples. Survival analysis indicated that high expression of GATA1, GATA2, and GATA4 were significantly correlated with better OS, while increased GATA3 and GATA6 expression were associated with worse prognosis in OC patients. The genetic variation and interaction of the GATA family may be closely related to the pathogenesis and prognosis of OC, and the regulatory network composed of GATA family genes and their neighboring genes are mainly involved in Notch signalling pathway, Th1 and Th2 cell differentiation and Hippo signalling pathway. Our results might be beneficial for the better understanding of heterogeneity and complexity in the molecular biology of $\mathrm{OC}$, and paving a way for more accurate prediction of the prognosis of patients with $\mathrm{OC}$.

\section{Declarations}

\section{Ethics approval and consent to participate}

All protocols and experiments in this study conformed to the Declaration of Helsinki and were approved by the Academic Committee of Zhongnan Hospital of Wuhan University. The data used in this study were obtained from published reports.

\section{Consent for publication}

Not applicable.

\section{Availability of data and material}

All data comes from commonly used public databases, and there is no need to provide additional statement of permission/consent for these databases. All data generated or analyzed during this study are included in this published article. 


\section{Competing interests}

The authors declare no competing financial interests.

\section{Funding}

This study was supported by project grants from the Yichang Medical and Health Research Project (A17301-12).

\section{Authors' contributions}

1. Z. and YL.T participated in the design of the study. Q.Z and HJ.Y. wrote the main manuscript text. Q.Z and MZ.Z participated in the research of the study and performed the statistical analysis. YL.T. HJ.Y and MZ.Z revised and polished the manuscript text. All authors reviewed the manuscript.

\section{Acknowledgements}

We thank the Oncomine, GEPIA, Kaplan-Meier plotter, cBioPortal, and Metascape for sharing the large amounts of data.

\section{References}

1. Siegel RL, Miller KD, Jemal A: Cancer Statistics, 2017. CA: a cancer journal for clinicians 2017, 67(1):7-30.

2. Torre LA, Bray F, Siegel RL, Ferlay J, Lortet-Tieulent J, Jemal A. Global cancer statistics, 2012. Cancer J Clin. 2015;65(2):87-108.

3. Jin J. Screening for Ovarian Cancer. Jama. 2018;319(6):624.

4. Force USPST, Grossman DC, Curry SJ, Owens DK, Barry MJ, Davidson KW, Doubeni CA, Epling JW Jr, Kemper AR, Krist AH, et al. Screening for Ovarian Cancer: US Preventive Services Task Force Recommendation Statement. Jama. 2018;319(6):588-94.

5. Kim SJ, Rosen B, Fan I, Ivanova A, McLaughlin JR, Risch H, Narod SA, Kotsopoulos J. Epidemiologic factors that predict long-term survival following a diagnosis of epithelial ovarian cancer. British journal of cancer. 2017;116(7):964-71.

6. Zheng R, Blobel GA. GATA Transcription Factors and Cancer. Genes cancer. 2010;1(12):1178-88.

7. Lentjes MH, Niessen HE, Akiyama Y, de Bruine AP, Melotte V, van Engeland M. The emerging role of GATA transcription factors in development and disease. Expert Rev Mol Med. 2016;18:e3.

8. Ohneda K, Yamamoto M. Roles of hematopoietic transcription factors GATA-1 and GATA-2 in the development of red blood cell lineage. Acta haematologica. 2002;108(4):237-45. 
9. Fang SH, Chen Y, Weigel RJ. GATA-3 as a marker of hormone response in breast cancer. J Surg Res. 2009;157(2):290-5.

10. Divine JK, Staloch LJ, Haveri H, Jacobsen CM, Wilson DB, Heikinheimo M, Simon TC: GATA-4, GATA5, and GATA-6 activate the rat liver fatty acid binding protein gene in concert with HNF-1alpha. American journal of physiology Gastrointestinal and liver physiology 2004, 287(5):G1086-1099.

11. Vuorenoja S, Rivero-Muller A, Kiiveri S, Bielinska M, Heikinheimo M, Wilson DB, Huhtaniemi IT, Rahman NA. Adrenocortical tumorigenesis, luteinizing hormone receptor and transcription factors GATA-4 and GATA-6. Molecular cellular endocrinology. 2007;269(1-2):38-45.

12. Akiyama $Y$, Watkins $N$, Suzuki $H$, Jair $K W$, van Engeland $M$, Esteller $M$, Sakai $H$, Ren $C Y$, Yuasa $Y$, Herman JG, et al. GATA-4 and GATA-5 transcription factor genes and potential downstream antitumor target genes are epigenetically silenced in colorectal and gastric cancer. Molecular cellular biology. 2003;23(23):8429-39.

13. Maeda M, Ohashi K, Ohashi-Kobayashi A. Further extension of mammalian GATA-6. Development growth differentiation. 2005;47(9):591-600.

14. Gai Z, Gui T, Muragaki Y. The function of TRPS1 in the development and differentiation of bone, kidney, and hair follicles. Histology histopathology. 2011;26(7):915-21.

15. Fujiwara T. GATA Transcription Factors: Basic Principles and Related Human Disorders. Tohoku J Exp Med. 2017;242(2):83-91.

16. Guo Y, Yu P, Liu Z, Maimaiti Y, Chen C, Zhang Y, Yin X, Wang S, Liu C, Huang T: Prognostic and clinicopathological value of GATA binding protein 3 in breast cancer. A systematic review and metaanalysis. PloS one 2017, 12(4):e0174843.

17. Shureiqi I, Zuo X, Broaddus R, Wu Y, Guan B, Morris JS, Lippman SM. The transcription factor GATA-6 is overexpressed in vivo and contributes to silencing 15-LOX-1 in vitro in human colon cancer. FASEB journal: official publication of the Federation of American Societies for Experimental Biology. 2007;21(3):743-53.

18. Hashiguchi T, Miyoshi H, Nakashima K, Yokoyama S, Matsumoto R, Murakami D, Mitsuoka M, Takamori S, Akagi Y, Ohshima K. Prognostic impact of GATA binding protein-3 expression in primary lung adenocarcinoma. Human pathology. 2017;63:157-64.

19. Wen XZ, Akiyama Y, Pan KF, Liu ZJ, Lu ZM, Zhou J, Gu LK, Dong CX, Zhu BD, Ji JF, et al. Methylation of GATA-4 and GATA-5 and development of sporadic gastric carcinomas. World journal of gastroenterology. 2010;16(10):1201-8.

20. Fu B, Luo M, Lakkur S, Lucito R, lacobuzio-Donahue CA. Frequent genomic copy number gain and overexpression of GATA-6 in pancreatic carcinoma. Cancer Biol Ther. 2008;7(10):1593-601.

21. Kyronlahti A, Ramo M, Tamminen M, Unkila-Kallio L, Butzow R, Leminen A, Nemer M, Rahman N, Huhtaniemi I, Heikinheimo M, et al. GATA-4 regulates Bcl-2 expression in ovarian granulosa cell tumors. Endocrinology. 2008;149(11):5635-42.

22. McEachin MD, Xu XX, Santoianni RA, Lawson D, Cotsonis G, Cohen C. GATA-4 and GATA-6 expression in human ovarian surface epithelial carcinoma. Applied immunohistochemistry molecular 
morphology: AIMM. 2008;16(2):153-8.

23. Caslini C, Capo-chichi CD, Roland IH, Nicolas E, Yeung AT, Xu XX. Histone modifications silence the GATA transcription factor genes in ovarian cancer. Oncogene. 2006;25(39):5446-61.

24. Wakana K, Akiyama Y, Aso T, Yuasa Y. Involvement of GATA-4/-5 transcription factors in ovarian carcinogenesis. Cancer letters. 2006;241(2):281-8.

25. Capo-chichi CD, Roland IH, Vanderveer L, Bao R, Yamagata T, Hirai H, Cohen C, Hamilton TC, Godwin AK, Xu XX. Anomalous expression of epithelial differentiation-determining GATA factors in ovarian tumorigenesis. Cancer research. 2003;63(16):4967-77.

26. Laitinen MP, Anttonen M, Ketola I, Wilson DB, Ritvos O, Butzow R, Heikinheimo M. Transcription factors GATA-4 and GATA- 6 and a GATA family cofactor, FOG-2, are expressed in human ovary and sex cord-derived ovarian tumors. J Clin Endocrinol Metab. 2000;85(9):3476-83.

27. Rhodes DR, Yu J, Shanker K, Deshpande N, Varambally R, Ghosh D, Barrette T, Pandey A, Chinnaiyan AM. ONCOMINE: a cancer microarray database and integrated data-mining platform. Neoplasia. 2004;6(1):1-6.

28. Rhodes DR, Kalyana-Sundaram S, Mahavisno V, Varambally R, Yu J, Briggs BB, Barrette TR, Anstet MJ, Kincead-Beal C, Kulkarni P, et al. Oncomine 3.0: genes, pathways, and networks in a collection of 18,000 cancer gene expression profiles. Neoplasia. 2007;9(2):166-80.

29. Barretina J, Caponigro G, Stransky N, Venkatesan K, Margolin AA, Kim S, Wilson CJ, Lehar J, Kryukov GV, Sonkin D, et al. The Cancer Cell Line Encyclopedia enables predictive modelling of anticancer drug sensitivity. Nature. 2012;483(7391):603-7.

30. Gyorffy B, Lanczky A, Eklund AC, Denkert C, Budczies J, Li Q, Szallasi Z. An online survival analysis tool to rapidly assess the effect of 22,277 genes on breast cancer prognosis using microarray data of 1,809 patients. Breast cancer research treatment. 2010;123(3):725-31.

31. Gyorffy B, Surowiak P, Budczies J, Lanczky A. Online survival analysis software to assess the prognostic value of biomarkers using transcriptomic data in non-small-cell lung cancer. PloS one. 2013;8(12):e82241.

32. Gyorffy B, Lanczky A, Szallasi Z. Implementing an online tool for genome-wide validation of survivalassociated biomarkers in ovarian-cancer using microarray data from 1287 patients. Endocrinerelated Cancer. 2012;19(2):197-208.

33. Cerami E, Gao J, Dogrusoz U, Gross BE, Sumer SO, Aksoy BA, Jacobsen A, Byrne CJ, Heuer ML, Larsson $\mathrm{E}$, et al. The cBio cancer genomics portal: an open platform for exploring multidimensional cancer genomics data. Cancer discovery. 2012;2(5):401-4.

34. Lowry JA, Mackay JP. GATA-1: one protein, many partners. Int J Biochem Cell Biol. 2006;38(1):6-11.

35. Migliaccio AR, Rana RA, Vannucchi AM, Manzoli FA. Role of GATA-1 in normal and neoplastic hemopoiesis. Ann N Y Acad Sci. 2005;1044:142-58.

36. Morceau F, Schnekenburger M, Dicato M, Diederich M. GATA-1: friends, brothers, and coworkers. Ann N Y Acad Sci. 2004;1030:537-54. 
37. Zhang Y, Liu J, Lin J, Zhou L, Song Y, Wei B, Luo X, Chen Z, Chen Y, Xiong J, et al. The transcription factor GATA1 and the histone methyltransferase SET7 interact to promote VEGF-mediated angiogenesis and tumor growth and predict clinical outcome of breast cancer. Oncotarget. 2016;7(9):9859-75.

38. Li Y, Ke Q, Shao Y, Zhu G, Li Y, Geng N, Jin F, Li F. GATA1 induces epithelial-mesenchymal transition in breast cancer cells through PAK5 oncogenic signaling. Oncotarget. 2015;6(6):4345-56.

39. Rodrigues NP, Tipping AJ, Wang Z, Enver T. GATA-2 mediated regulation of normal hematopoietic stem/progenitor cell function, myelodysplasia and myeloid leukemia. Int J Biochem Cell Biol. 2012;44(3):457-60.

40. Rodriguez-Bravo V, Carceles-Cordon M, Hoshida Y, Cordon-Cardo C, Galsky MD, Domingo-Domenech $\mathrm{J}$. The role of GATA2 in lethal prostate cancer aggressiveness. Nature reviews Urology. 2017;14(1):38-48.

41. Wang $Y, H e X$, Ngeow J, Eng C. GATA2 negatively regulates PTEN by preventing nuclear translocation of androgen receptor and by androgen-independent suppression of PTEN transcription in breast cancer. Human molecular genetics. 2012;21(3):569-76.

42. Liu X, Jiang B, Wang A, Di J, Wang Z, Chen L, Su X. GATA2 rs2335052 Polymorphism Predicts the Survival of Patients with Colorectal Cancer. PloS one. 2015;10(8):e0136020.

43. Hamadou WS, Mani R, Besbes S, Bourdon V, Youssef YB, Eisinger F, Mari V, Gesta P, Dreyfus H, Bonadona $\mathrm{V}$, et al. GATA2 gene analysis in several forms of hematological malignancies including familial aggregations. Annals of hematology. 2017;96(10):1635-9.

44. Asch-Kendrick R, Cimino-Mathews A. The role of GATA3 in breast carcinomas: a review. Human pathology. 2016;48:37-47.

45. Li Y, Ishiguro H, Kawahara T, Miyamoto Y, Izumi K, Miyamoto H. GATA3 in the urinary bladder: suppression of neoplastic transformation and down-regulation by androgens. American journal of cancer research. 2014;4(5):461-73.

46. Du F, Yuan P, Wang T, Zhao J, Zhao Z, Luo Y, Xu B. The Significance and Therapeutic Potential of GATA3 Expression and Mutation in Breast Cancer: A Systematic Review. Medicinal research reviews. 2015;35(6):1300-15.

47. Howitt BE, Emori MM, Drapkin R, Gaspar C, Barletta JA, Nucci MR, McCluggage WG, Oliva E, Hirsch MS. GATA3 Is a Sensitive and Specific Marker of Benign and Malignant Mesonephric Lesions in the Lower Female Genital Tract. Am J Surg Pathol. 2015;39(10):1411-9.

48. Fu B, Guo M, Wang S, Campagna D, Luo M, Herman JG, lacobuzio-Donahue CA. Evaluation of GATA4 and GATA- 5 methylation profiles in human pancreatic cancers indicate promoter methylation patterns distinct from other human tumor types. Cancer Biol Ther. 2007;6(10):1546-52.

49. Aronson BE, Stapleton KA, Krasinski SD. Role of GATA factors in development, differentiation, and homeostasis of the small intestinal epithelium. American journal of physiology Gastrointestinal liver physiology. 2014;306(6):G474-90. 
50. Wang H, Liu Z, Li J, Zhao X, Wang Z, Xu H. DeltaNp63alpha mediates proliferation and apoptosis in human gastric cancer cells by the regulation of GATA-6. Neoplasma. 2012;59(4):416-23.

51. Castro IC, Breiling A, Luetkenhaus K, Ceteci F, Hausmann S, Kress S, Lyko F, Rudel T, Rapp UR. MYCinduced epigenetic activation of GATA4 in lung adenocarcinoma. Molecular cancer research: MCR. 2013;11(2):161-72.

52. Zois E, Vollstadt-Klein S, Hoffmann S, Reinhard I, Bach P, Charlet K, Beck A, Treutlein J, Frank J, Jorde A, et al. GATA4 variant interaction with brain limbic structure and relapse risk: A voxel-based morphometry study. European neuropsychopharmacology: the journal of the European College of Neuropsychopharmacology. 2016;26(9):1431-7.

\section{Figures}
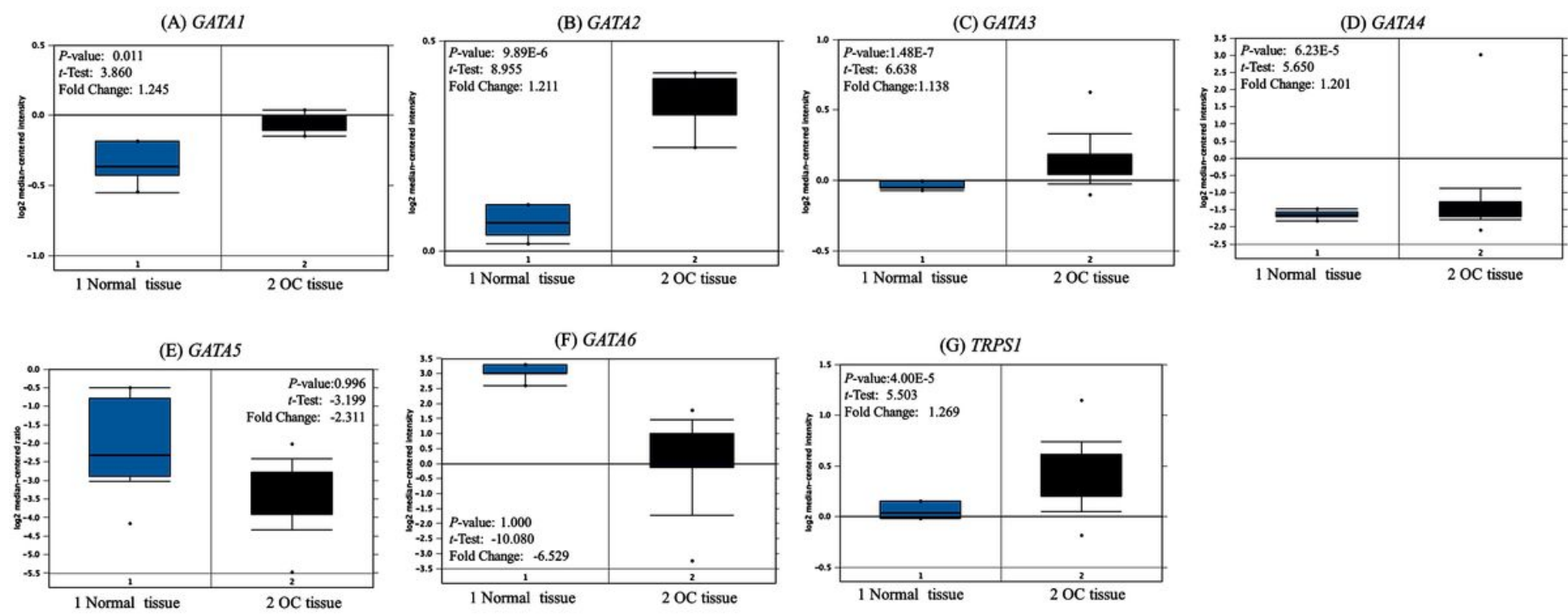

\section{Figure 1}

GATA family analysis in ovarian cancer (ONCOMINE database). (A) Comparison of GATA1 mRNA expression (Probe IDs: 210046_at). (B) Comparison of GATA2 mRNA expression (Probe IDs: 210358_x_at). (C) Comparison of GATA3 mRNA expression (Probe IDs: 209604s_at). (D) Comparison of GATA4 mRNA expression (Probe IDs: 205517_at). (E) Comparison of GATA5 mRNA expression (Probe IDs: A_23_P132048). (F) Comparison of GATA6 mRNA expression (Probe IDs: U66075_at). (G) Comparison of TRPS1 mRNA expression in normal and primary OC tissues (Probe IDs: 218502_s_at). 


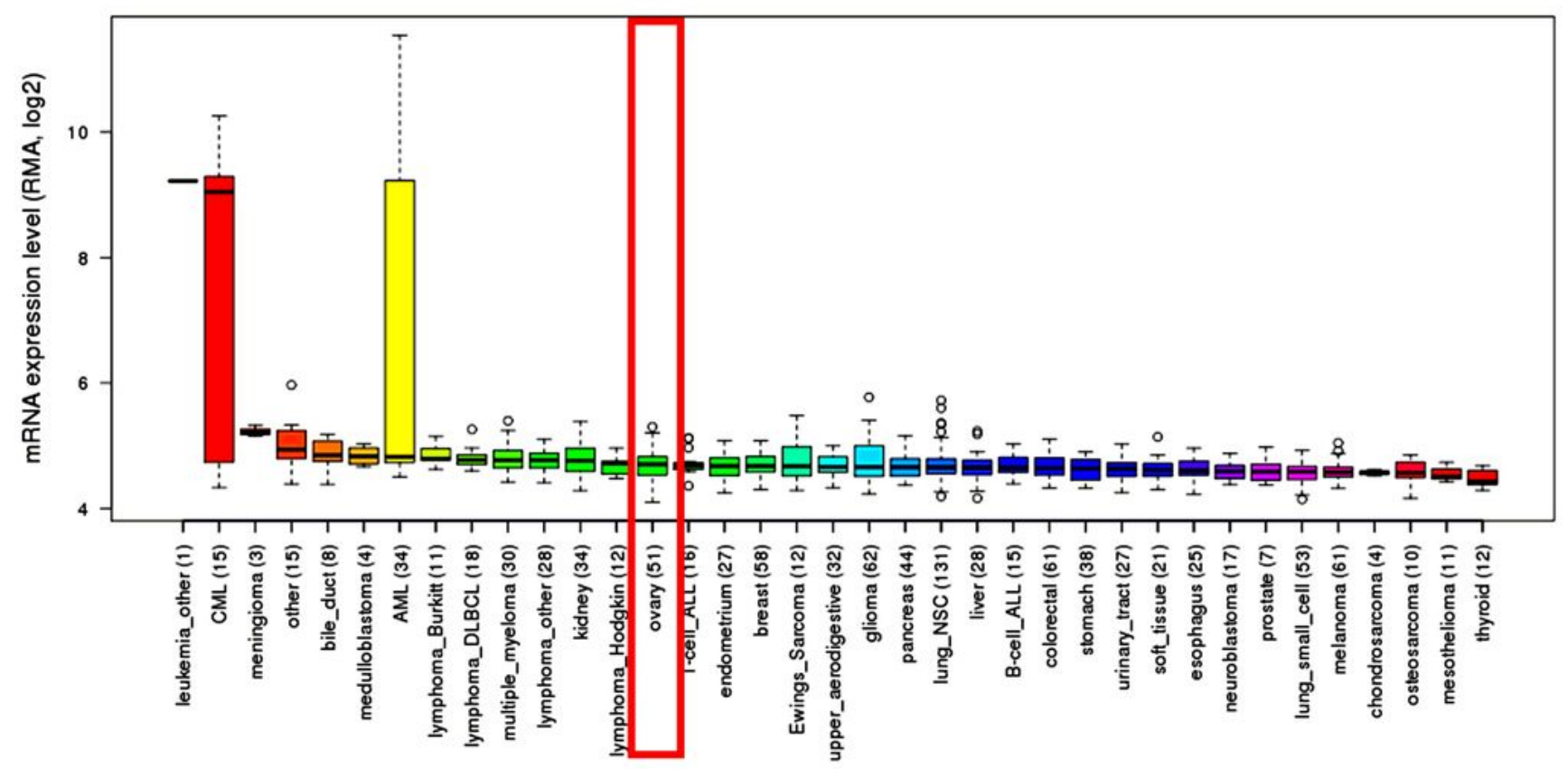

\section{GATA2 - Entrez ID: 2624}

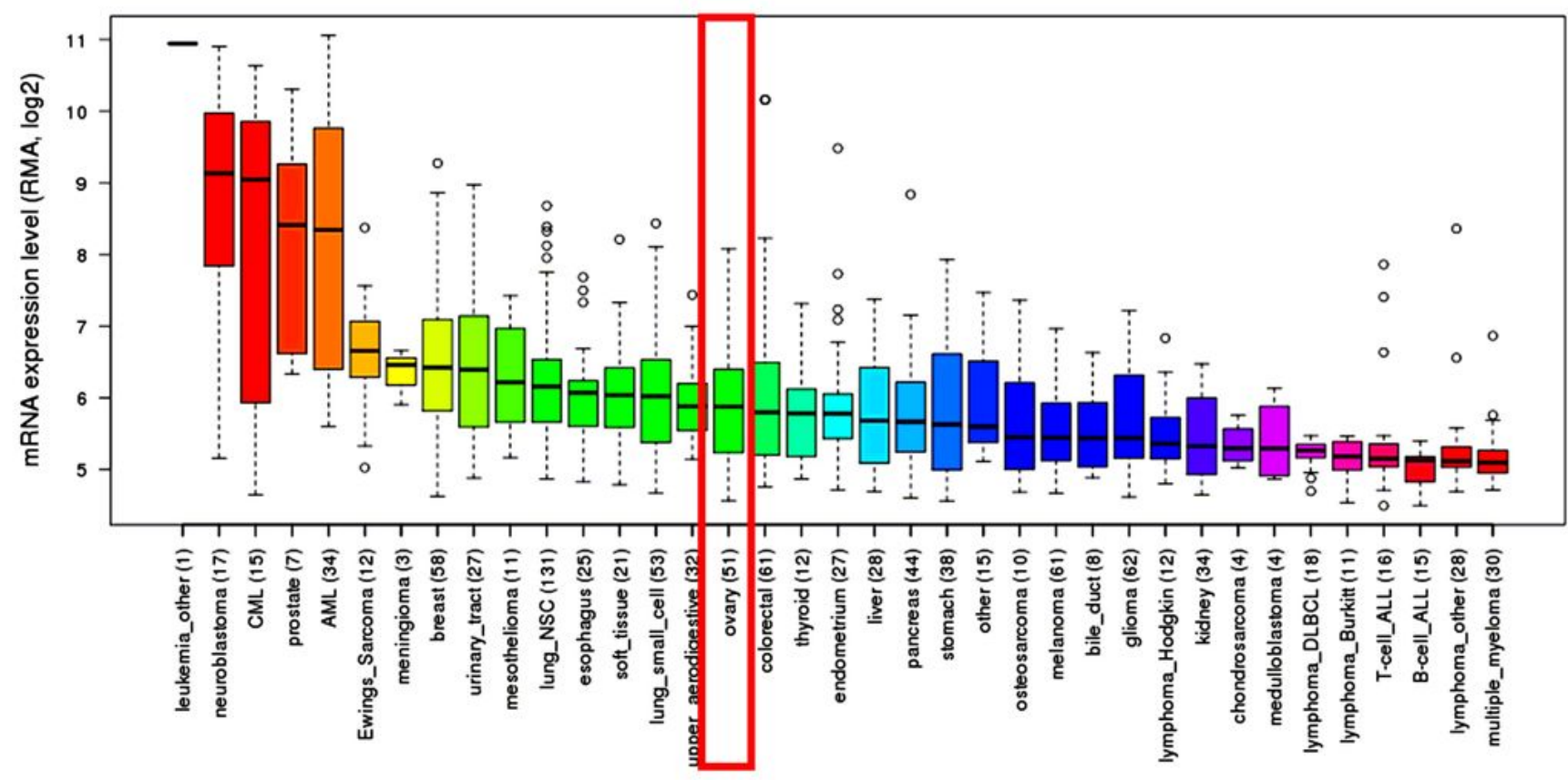

Figure 2

GATA1 and GATA2 were distinctively high expressed in ovarian cancer cell lines from CCLE analysis (CCLE database). (A) The mRNA expression levels of GATA1 ranked the 14th highest in OC among different cancer cell types. (B)The mRNA expression level of GATA2 ranked the14th highest in a variety of cancer cell line. 

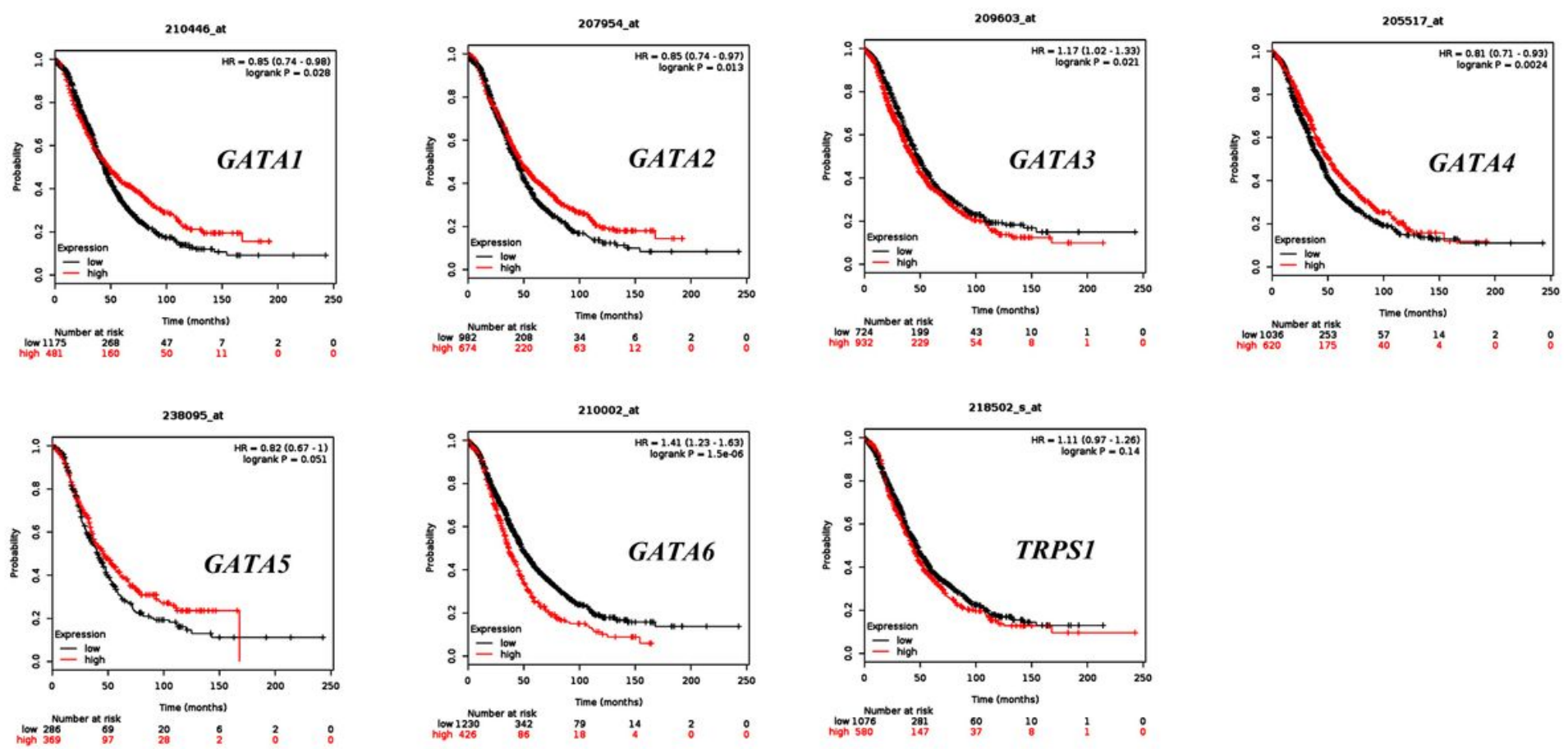

\section{Figure 3}

The prognostic value of mRNA level of GATA family members in OC patients (Kaplan-Meier plotter database). We chose the probe with the largest sample size as the target probe for further analysis when multiple probes correspond to the same GATA family member. Survival curves of (A) GATA1 (Probe IDs: 210446_at), (B)GATA2(Probe IDs: 207954_at)『(C)GATA3(Probe IDs: 209603_at)®(D)GATA4(Probe IDs: 205517_at), (E)GATA5 (Probe IDs: 238095_at), (F)GATA6(Probe IDs: 210002_at)囚(G)TRPS1(Probe IDs: 218502_s_at) are plotted for all patients $(n=1,186)$. 


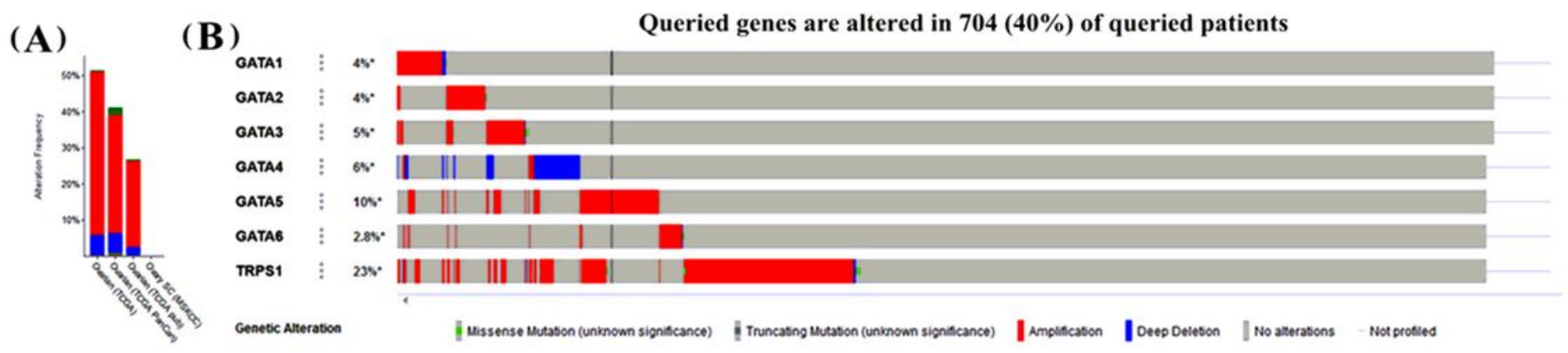

(C)

\begin{tabular}{|c|c|c|c|c|c|c|c|}
\hline & GATAI & GATA2 & GATA3 & $G A T A 4$ & GATAS & GATA6 & TRPSI \\
\hline GATAI & 1.00 & -0.00 & 0.07 & 0.00 & 0.01 & -0.04 & -0.05 \\
\hline GATA2 & -0.00 & 1.00 & 0.05 & 0.01 & 0.01 & -0.12 & -0.07 \\
\hline GATA3 & 0.07 & 0.05 & 1.00 & -0.10 & -0.06 & -0.12 & 0.09 \\
\hline GATA4 & 0.00 & 0.01 & -0.10 & 1.00 & 0.16 & 0.20 & -0.07 \\
\hline GATAS & 0.01 & 0.01 & -0.06 & 0.16 & 1.00 & -0.21 & -0.11 \\
\hline GATA6 & -0.04 & -0.12 & -0.12 & 0.20 & -0.21 & 1.00 & 0.23 \\
\hline \multirow[t]{2}{*}{ TRPS1 } & -0.05 & -0.07 & 0.09 & -0.07 & -0.11 & 0.23 & 1.00 \\
\hline & -0.21 & & & & & 1.00 & \\
\hline
\end{tabular}

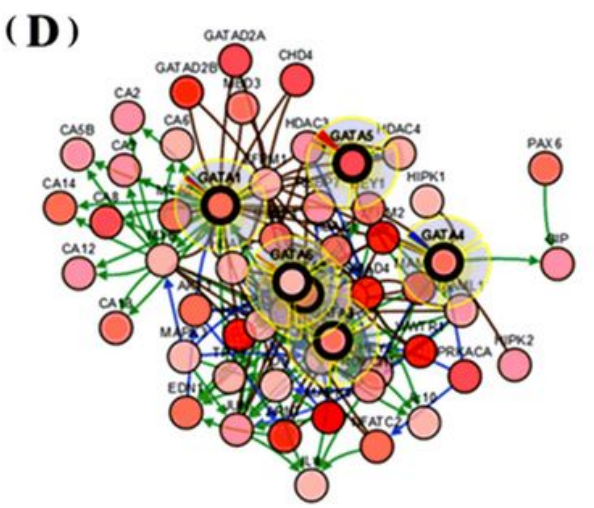

(E)

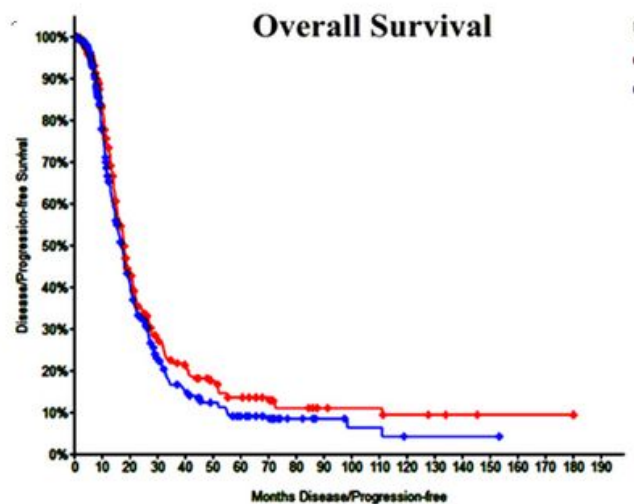

(F)

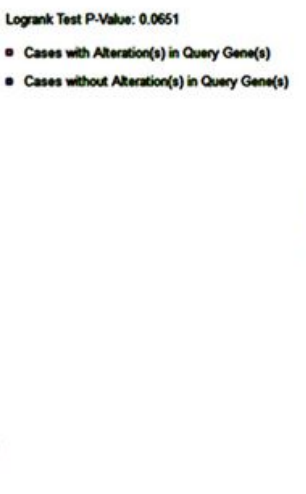

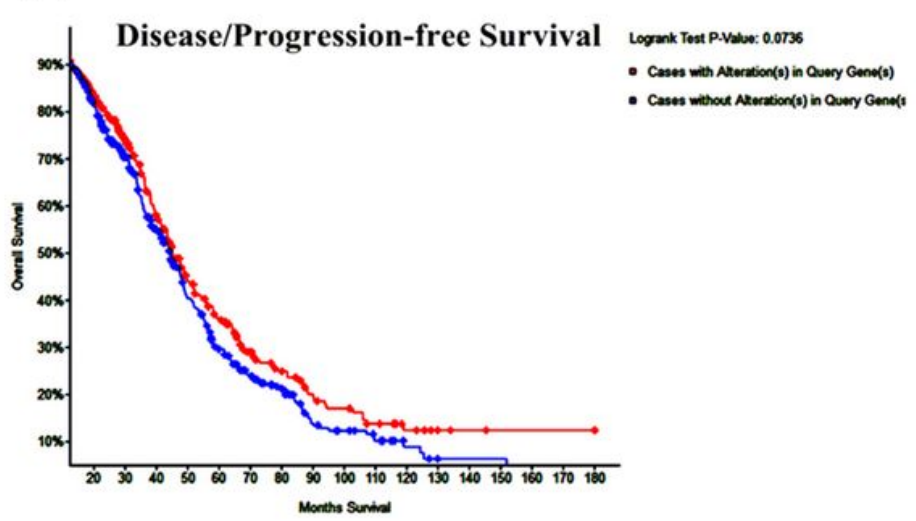

Figure 4

Alteration frequency and interaction analysis of GATA family numbers and neighbor genes network in OC patients (TCGA and cBioPortal database). (A) Summary of alteration on GATA family numbers. (B) OncoPrint visual summary of alteration on a query of GATA family numbers. (C) Pearson correlation of GATA family members. (D) Gene-gene interaction network among GATA family members in TCGA Provisional dataset, light blue represents controls state change relationship, Light green represents controls expression relationship and Brown represents the complex relationship between genes.(E) The results of Kaplan-Meier plotter and log-rank test indicated no significant difference in OS between the cases with alterations in one of the query genes and those without alterations in any query genes $(P$ values, 0.0651). (F) The results of Kaplan-Meier plotter and log-rank test indicated no significant 
difference in DFS or PFS between the cases with alterations in one of the query genes and those without alterations in any query genes ( $P$ values, 0.0736).

(A) GO:BP

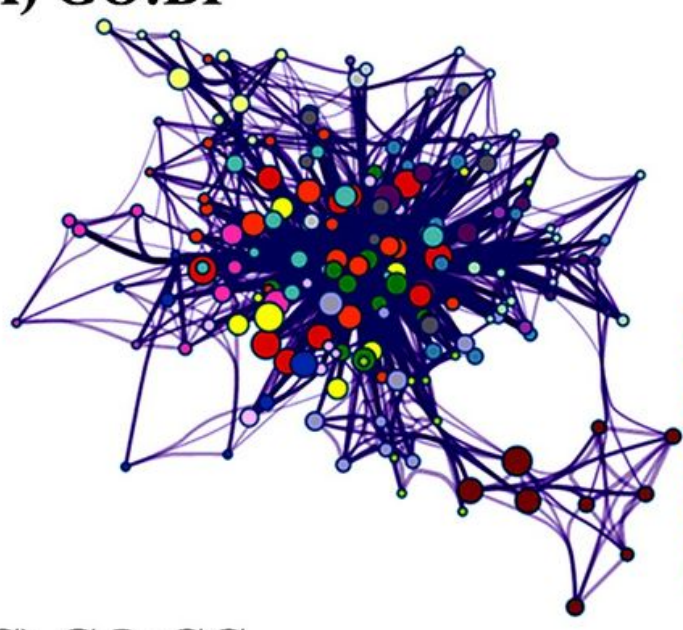

(C) GO:CC

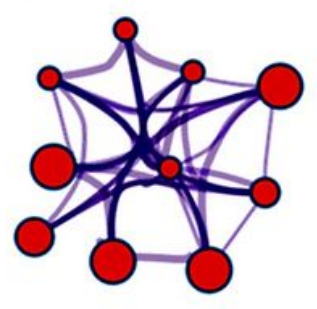

1

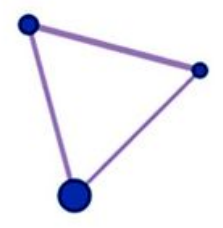

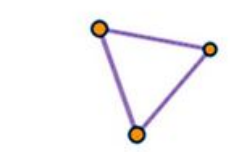

(B) GO:MF

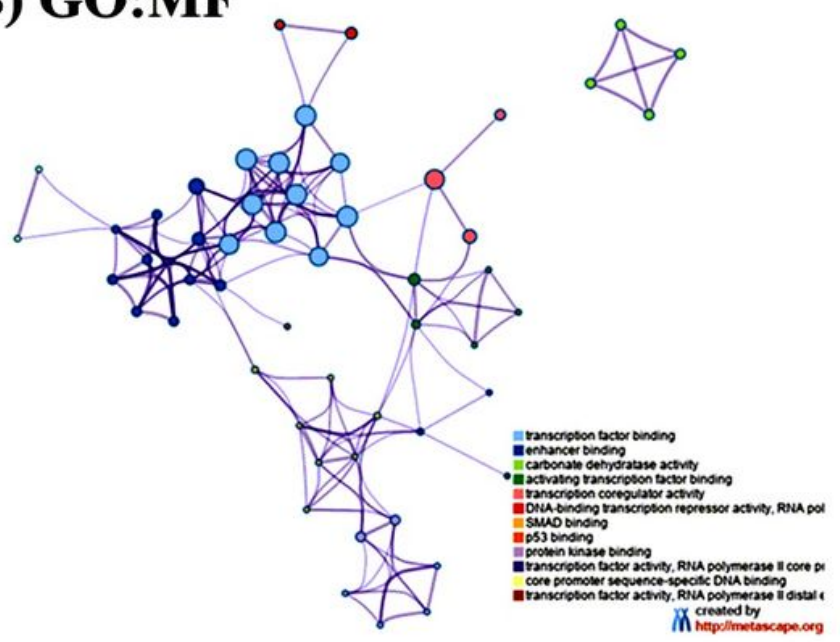

(D) KEGG

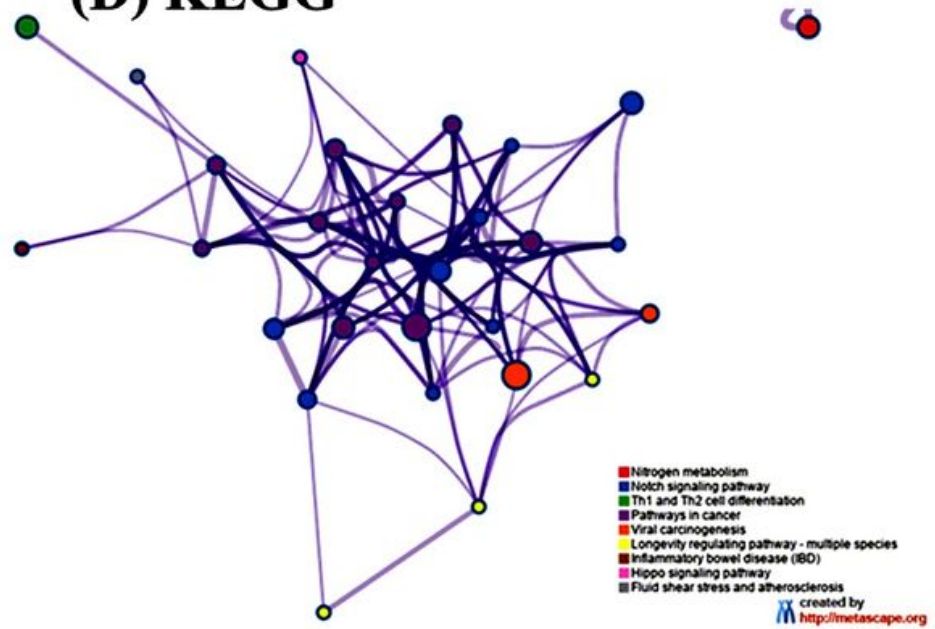

Figure 5

Functions enrichment analysis of GATA family members and their neighboring genes in patients with OC (Metascape database). The Gene Ontology (GO) terms for the (A) biological process (BP), (B) cellular component (CC), (C) molecular function (MF) and (D) Kyoto Encyclopedia of Genes and Genomes (KEGG) pathways were enriched based on Metascape online tool. 
(A)

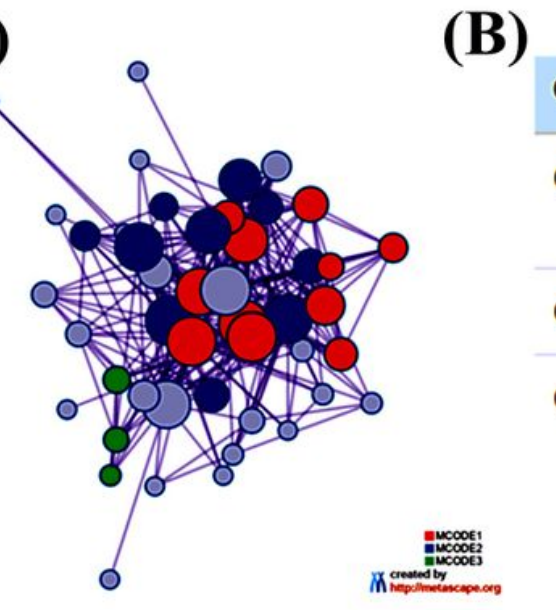

(C)
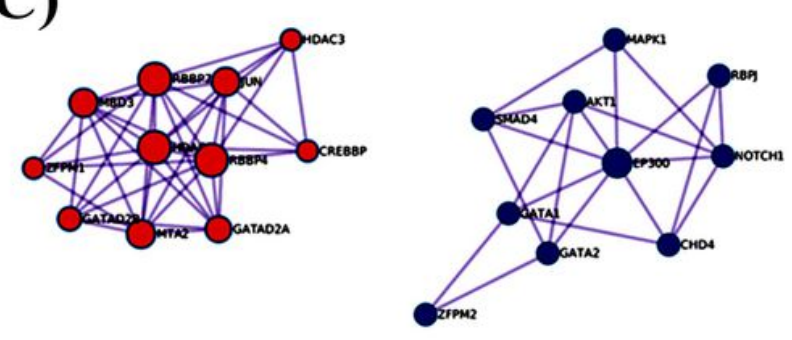

Description

GO:0000976

GO:0008134 transcription factor binding

GO:0000987 proximal promoter sequence-specific DNA binding

DNA binding $\log 10(P)$

$-33.9$

$-33.2$

$-32.1$

(D)

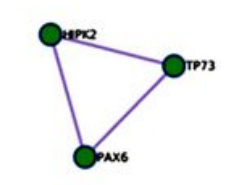

\begin{tabular}{|c|c|c|c|c|}
\hline & MCODE_2 & GO:0043009 & chordate embryonic development & -13.6 \\
\hline & MCODE_2 & GO:0009792 & $\begin{array}{l}\text { embryo development ending in } \\
\text { birth or egg hatching }\end{array}$ & -13.5 \\
\hline & MCODE_2 & GO:0001701 & in utero embryonic development & -13.4 \\
\hline 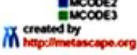 & MCODE_3 & GO:0008134 & transcription factor binding & -4.7 \\
\hline
\end{tabular}

Figure 6

Protein-protein interaction network and MCODE components among GATA family members and their neighboring genes (Metascape database). (A) Protein-protein interaction (PPI) network. (B) GO Function enrichment analysis of PPI network. (C) Three most significant MCODE components form PPI network. (D) Function enrichment analysis of three MCODE components independently among GATA family members and their neighboring genes.

\section{Supplementary Files}

This is a list of supplementary files associated with this preprint. Click to download.

- FigureS1.tiff 